\title{
風水思想における自然景観の捉え方に関する研究
}

\section{The Understanding of the Natural Landscape in the Idea of Feng-shui}

\author{
黄 永融* \\ Yung-jung HUANG
}

\begin{abstract}
摘要 : 東洋思想の一つであった風水思想は大地を生きたものとして扱っている。風水思想において大 自然の山は，単なる土と鉱物を混在するものでなく，一個生命をもつ「龍」である。風水では，石は 山の骨であり，土は山の肉であり，川は山の血脈であり，草木はその皮毛である。そして骨肉皮毛は 血脈によって貫通したのである”。こうした大地は疑似人体と見なされ，人間は自然と一体にならな ければならないという「天人合一」の思惟が定着した。また，風水は一種の実用技術でもあり，大自 然の風景を読みとり，自然の原則に従って造営物や空間をつくるという東洋の独特な自然景観論とし て位置づけられる。
\end{abstract}

\section{1.はじめに}

近代の地理学における物理的環境論が，大地を鉣物，無生物と して扱う理念であるのに対し，東洋思想の一つである風水思想で は大地を生きたものとして扱っている。つまり風水では大地は単 に有形の物質体であるに止まらず，人間と同じように血肉躯体が 揃った生物であり，しかも自然環境に与える影響は人間も同様に 感応を受けられるという自然と人間とを互動させる関係をむつと いう思考方法を取る。したがって物理的な地理観での自然と人間 の二元論に対し，風水の見方では人間は自然の中の一部であると 考えられ，人間の生き方は自然と共存・共生，さらに自然と一体 にならなければならないという「天人合一」（自然と人間は一体 になる）の思想論が定着した。

また，風水は一種の実用技術でもあり，古人の無数の優れた生 活経験を蓄積して作った法則であると屯考えられる。つまり大自 然の風景を読みとり, 自然の原則に従って周井の自然環境亡調和 するように造営物や空間をつくるという自然景観に配慮した計画 論として位置づけられる。

風水論の歴史的な検証や風水の実際の適用に関する分析につい ては，これまで日本の古代宮都 ${ }^{2)}$ 及び台北の市街地 ${ }^{3)}$ を事例とし た研究で行ってきた。本論文は, 一連の研究をより進展させる目 的で，文献調查に基づき，風水論に含まれている自然景観に配慮 した計画概念の整理を目的としたものである。なお，風水理論に は，自然地形，景観を重視する「形派」と羅盤（コンパス）を用 いて方位を見る「理派」という二つの流れがあるが，本論では， 風水形派による定義の解釈から風水の基本理念を究明し, さらに 風水の実践技法の分析を通じて，風水思想による自然景観の捉え 方について考察を加えて行きたい。

\section{2. 自然環境から生まれた風水の語義}

「風水」は「堪興」「地理」或いは「陰陽」とも呼ばれる。こ の「堪興」については，「堪とは天道であり，興とは地道である。」 と東漢の許慎が『淮南子』の「天文訓」に記し，また，「地を興 と為すと謂ふ者は, 天地覆蓋の徳有り, 故に天を蓋と為すと謂ひ, 地を興と為すと謂ふ。」と『史記』にもある。これによれば「堪 興」は天地を指し，またその天地の変化を観察することだという。 その他，『易経・繋辞伝上』では，「仰いで以て天文を観，俯いで 以て地理を察す。此の故に幽明の故を知るなり」之記されており,
この「幽明」とは，現在の言葉で言うと「宇宙」や「自然」を指 しており，簡単に言えば，天文を観察し自然を認識することで， 宇宙の万象が理解できるということである。

また，「地理」からの説明を試みれば，中国の古代社会にあっ ては，地理を観察し，地勢を相するという考え方があったため， 風水の起源は生活経験などに基づいた古代の「地形学」であると 考えられる。つまり，風水とは自然の地形地物や四季の気候変化 などを観察することで，さらに人間に対して好適な居住環境を選 択する技術である。

さらに「陰陽」という別名であ呼ばれているが，これは陰陽を 基本原理とした風水思想では自然地形の高低，凸凹，突陷などの 現象を，すべて陰と陽で解釈しているからである。唐の国師であっ た楊均松の『青鳥経註』によると，「陰陽符合すれば，天地交通 し, 内気萌生し, 外気成形し, 内外相乗なり, 風水自ら成る」 とあり,つまり, 風水にふさ わしい地形があれば，「陰陽 調和」の状態になれるという ことである。

風水の理念では人間が生存 している大地をつつの太極と 考えている。太極とは陰と陽 に分けられる存在を意味し,

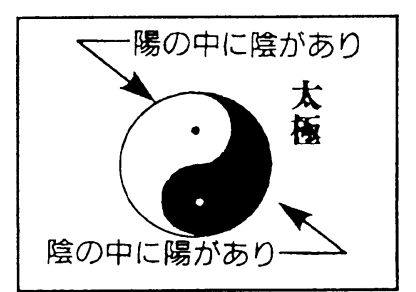

図一 1 太極図 さらに陰の中に陽があり，陽の中にも陰が存在しているとする概 念である（図一 1 )。その陰と陽を地形において具体的に説明す ると，陰は宿・低下の意味に対し，陽は突出・高起を象徵する。 風水による選地の手法では，その地形の「陰陽」を調和するよう に考える。それを太極の理念を用いて説明すると，太極とは陰と 陽から生成され，さらに陰の中に陽があり，陽は陰を含めると陰 陽安定の状態になる，ということになる。この理念に基づいて， 風水地形の選択の一つでは「高処取低」（すべて高所である地形 の中で低平の場所を選ぶ），「低処取高」（すべて平野である地域 では少々高い台地を探す）という原則となる。それは地形の高低・ 凸凹を調節し，陰陽調和を配慮するためである（図一2）。

「風水〕という言葉から考えれば，自然環境の中でももっとも 大切な要素が, 気候を大きく左右する「風」と「水」であり, 古 代人にとって, 天候の安定は生活の保障である。暴風や洪水が古 代人の敬畏の対象となり, それを避けまた安定した生活を確立す

•大阪大学工学部環境工学科 


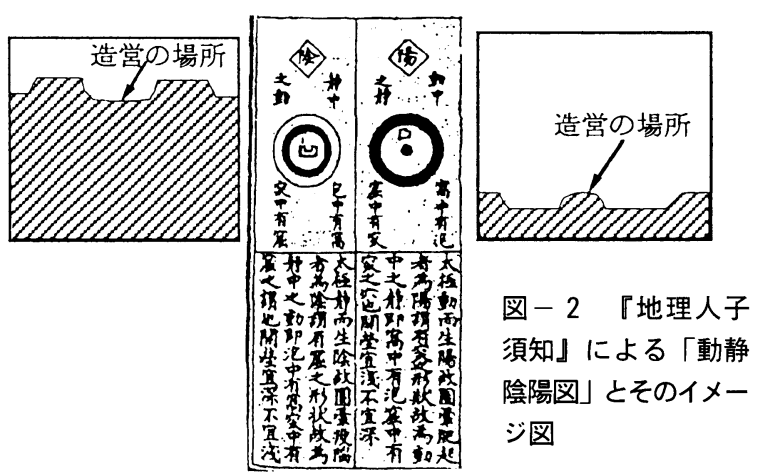

るためには「風」や「水」を制御することが基本と考えた。そう いった考えの根底にある自然現象の崇拝が，風水の起因の一っで あると考えられる。一方，風水思想はすべて「気」という概念て 成り立っていたのである。東洋思想におけるこの目に見えない 「気」とは万物の動源であり，その概念は「中国に古代から伝わ る宇宙・自然・生命を成り立たせている根元的生命力」と理解さ れている。気はたえまなく流動的な状態であり，重く濁り，また 軽く澄んた部分む存在している, その重く濁った状態を陰, 澄ん で軽くなった状態を陽と言い，これは陰陽両気が対立して存在す る状態である。この陰陽両気については郭璞の『葬経』によると, 「陰陽の気，叶き出すと風となり，昇ると雲となり，降りると雨 となり, 地中に流れている時は生気となる。」」 ${ }^{5)}$ とあり，陰陽の 気は地面上に出ると，風や雲・雨などの可視的な物質になる，地 中に潜って行けば, 不可視の「気」に変身する。また, 『葬経』 には「気は風に乗ずれば即ち散じ，水にへだてられれば止まる。 古人はこれを聚めて散ぜざらしめ，これを行かせるも止まること あらしむ。故にこれを風水之謂う。」崖文記され，これによると， 風水思想では, 可視的な「風」や「水」を制御するだけでなく, 地中に隠れた不可視的な「気」屯，止めたり集めたり工夫してい るのである。可視・不可視の二層性に基づいて，人間の生存環境 に強く関わっている「風」と「水」の両要素が「風水」という言 葉の起因と考えられる。

以上のような風水の語義からの検証によると，風水思想は人間 が存在する自然環境の観測に基づいて成立した生活の哲学ともい え，また，自然の条理にしたがって地上の諸施設の配置を合致さ せる計画論であある。

\section{3. 自然の山に生命を吹き込む「龍脈」概念}

風水思想によって自然地形に生命を与える様子を表したものが 龍脈理念である。「龍脈」とは，地表に起伏しながら連なって走 る山脈（山並み）をいう。なぜ自然の山が龍の姿に象徵されたか ということは, 明の『地理人子須知』に「地理家（風水師）は山 を以て龍と名づくは何ぞや, 山の変態が千形万象, 或は大或は小, 或は起き或伏す, 或は順ひ或は逆ふ, 或は隠れ或は顕れる...惟 だ龍を然と為す, 故に以て之を名づく, 其の潜見飛躍を取り, 変 化を測ることと莫し」7) という解釈が付けられている。また，龍 脈の源流とは, 中国の北西に位置した苌崙山であったと定説され, ここから北幹龍・中幹龍・南幹龍という三本の大龍脈が東に向い て走っていくのである（戍-3）。そしてこれらの龍脈は主脈か ら支脈に，さらに支脈から微山脈を生じ，樹木の幹，枝のように 大地の至る所に網状に分布していた。このような大地の筋になっ た龍脈のうち, 地表に隆起し山脈になるものを「山龍」といい, この龍脈が平野或いは平地にきて, 少し突起し, 土堤・台地になっ たものが「平陽龍」と呼ばれる。この龍脈の概念によると，地表 の高低差から少しでも高いものを山（龍脈）となし，一寸低いも のを水とする。したがって雨の降った場合，一寸低き地に水が流

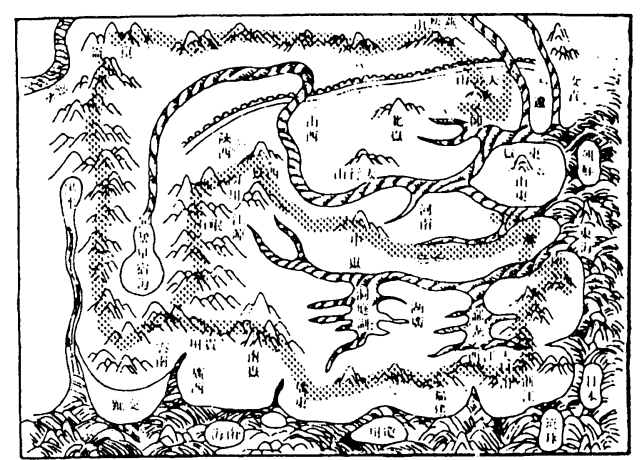

図一 3 『三図会』による中国の三大幹龍図

れれば, 一寸高き地は堤（龍脈）となる。つまり風水の見方は地 表の僅かな高低関係によって, 龍脈あり水あり之認めるのであり, 風水は自然環境の微地形を分析する技術であるとも考えられる。

\section{4. 大地を模擬人体とする風水理念}

風水思想では龍脈に沿って地中を流れる「父」はまた「地気」 とも呼ばれる。この地気は龍脈の中を均質に流れているわけでな く, 地形構造によって稠密になったり希薄になったりして, 水の ように流れている。この「気」は龍のように起伏して連続する山 脈の中を流れ，最も集中する所は「龍穴」という。また，その 「気」の集中した龍穴が吉祥地と見なされ，そこに都市や建物を 作れば大地の「気」を感応することによって繁栄できると信仰さ れていた。

風水の理念ではこの大地が模擬人体であって, 地下を龍脈に沿っ て走る「気脈」は，人間の身体を流れる脈に例えられ，人体の 「経絡」と対応しているとみなされている。この人体の血管・神 経とは別の循環系統である「経絡」は, 身体における気の道で, 気はそれに沿って全身を巡っている。大地も人体と同じように地 中に気が巡っていると考えられ，また，「気」の集中した龍穴は 身体の経絡における重要な鍼や尒のポイント「経穴」（ツボ）と 照応するのである。この概念について『地理人子須知』に「日は く脈（龍脈）なる者は何ぞや，人身の脈絡の由る所は運行し一身 なり」,「穴（龍穴）なる者は, 蓋し猶ほ人身の穴の如し」 ${ }^{8)}$ と, また『雪心賦』に「点穴 (龍穴) は猶ほ点艾 (众)の如し」 ${ }^{9)}$ と 記されている。

\section{5. 自然的景観を活用した風水技法}

\section{（1）「山河襟帯」の囲繞空間}

風水思想における理想的な地勢は何層にも山々に同まれた状態 である。具体的に言えば, 一種の「囲繞」の空間構造であり, 即 ち風水が追求する「気を聚めて散せず」という吉地の状態である。 風水理念において龍脈の中を流れている「気」には,「風に乗ず れば即ち散じ, 水にへだてられれば止まる」という原則があり， 「気〕が風に散らされないように, 山に囲まれる地形が望まれる のであり，また，「気」が停止せず去っていくことのないように， 川によって界する必要があると定められている。この「気」が洩 れないように, 敷地の四方をぐるりと囲む形になって, 風をおさ めることができる地形が，いわゆる「蔵風納水」（風を蔵する， 水を得る）の地形である ${ }^{10}$ 。こうした囲繞された地形によってそ の中に「気」が眝められ，万物がこの「気」によって育まれるの であり, 都市や集落・墓地などをそこに造ると, 莫大な幸福をも たらすことができると信仰されたので, 風水的な理想地形はその 「気」を囲い込むという「囲繞」の空間構造を選択したのである。 風水思想による都市や集落の選地は, 「山河㯲帯」の地で営む状 況がよく見られる(1)。こうした「山が襟のように取り囲み, 川が 带のように巡り流れ，自然の地勢を取り入れて都城や集落を造る」 
という造営法を，風水術ではよく着物の衿の打ち合わせと帯に囲 まれた様子に比喻するのである ${ }^{12)}$ 。しかし，風水で言う「囲繞」 とは，完全に閉じた空間ではなく，龍穴の所在地から周辺の山並 みを眺めた時，犬牙が交錯したような山脈の重なりにより一種の 閉鎖空間之感じられる状態を指し，視覚的な印象に基づく判断で あると見られる(図一 4 )。

\section{(2) 四方対称の「天心十道」論}

風水的な封鎖性のある空間構造について，もっと具体的に分析 すれば，それは前後左右が対称的な地形景観の存在と見られてい る。この理念は風水思想の中で「天心十道」で説明されていた ${ }^{13)}$ 。 「十道」というのは 論,「龍穴」（風水上の一番上い場所）の前 後左右に対称的に位置する山である。「天心」には「宇宙の中心 という意味があり勿論ここでは龍穴を指している。

この「天心十道」に要求される地形は, 前後に相対する山は左 右に偏してはいけない, 左右の山も高低の差がないという極めて 十字対称の地形であり, そういう地形構造を備えれば風水の吉地 となる。このように四方に対称的に囲まれた地形概念を，風水思 想では「四神相応」という言葉で表現している。

「四神相応」の起源を探求すると，それは中国古代の天文星象 においてみられたものである占)。古人の天文観念において天球を $90^{\circ}$ ごとに四つの象限に分け，そこにある七宿（七個玍群）づつ の星座を合わせて二十八宿と呼んだ。その四つの象限中の星群を それぞれつなげてできた形が，伝説中の青龍・白虎・朱雀・玄武 という四神獣の形態であり, 空の東・西・南・北に対称に存在し ている。風水術はその天文現象を具体化して, 自然地形の四方に 対して左は青龍, 右は白虎, 前は朱雀, 後は玄武という名称を与 え，これによって自然地形が前後左右に均等に対称でき，景観の バランスが取れる場所を「四神相応」の吉地と呼んだのである。 こうした地形の選択において対称な地形構造を重視する風水思想 に基づく理想的な地形構造とは，地形の縦軸が「主山一坐山一案 山一朝山」という山列を成し, 横軸に左右対称の「青龍・白虎」 の山を配し，またその山々に囲まれた空間として「明堂」がある という地形構造である(図-5)。

\section{（3）地形の基準点になった「案山」の形象}

風水による地形構造の見方では造営物を置くべき龍穴の前方の 近くに位置する山を「案山」という。案とは人の座前に使用する 机の意味で, 龍穴に対してまさにその机に相当する象徴的な山で ある。「案山」の選択については, 山の高さよりあ山稜線の形が 重視されている。造営物（都城・住宅・墓など）を置くべき龍穴 に面する「案山」は，いずれも秀麗な姿をした山が選定される。 たとえば, 三台山（三峰をもつ山）, 馬鞍山（鞍のような二つの 峰をむつ山), 筆架山（筆置きに似た姿で，三峰や五峰がある）, 横琴（横たえた琴に似た山）, 眠弓（弦を張らない弓に似た山）, その他は亀蛇, 天馬, 伏虎, 臥牛, 軍旗, 鏡台など, 動物から文 具や装飾品まで渡る名称をつけた山が揃っている（図一 6 )。こ うした風水の専門用語を使って命名された山や地名は, 中国全土 にわたってよく見出される(5)。

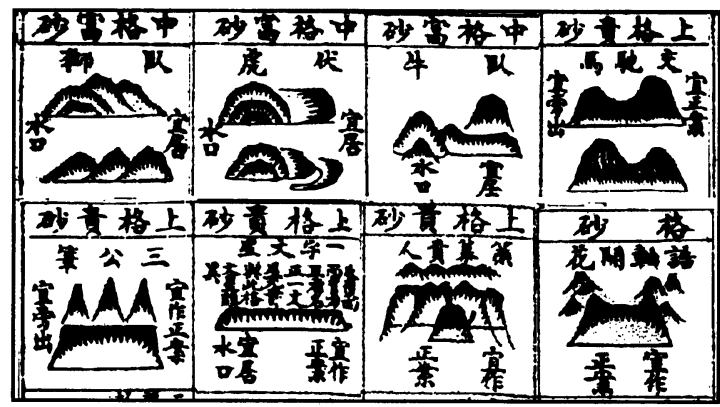

図一 6 宋・『龍格』明・『地理人子須知』による案山の形態

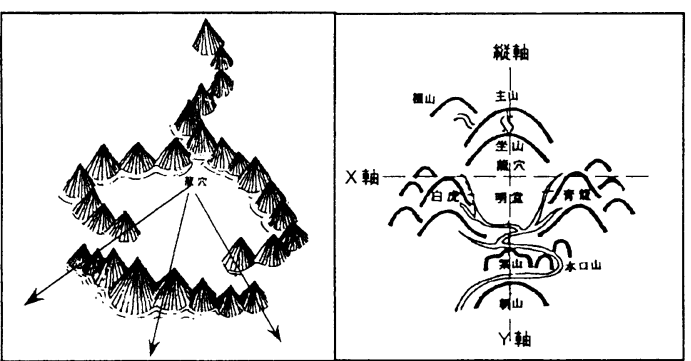

图ー4 龍穴を視点として見た囲繞空間 図-5 地形が四方対称となる天心十道論

このような山の形は風水書の中に数百種類に分けられている, これは龍穴に置く造営物の向きや位置が案山の所在地によって左 右されているからである。つまりまず建造物の向きが案山を前方 の基準点として決められるのである。その龍穴から案山を結んだ 線が，地形のプランにおいて大切な中軸線であり，これを中心之 して建造物の全体プランが左右対称に作られた。さらに，案山を 基準点として造ったプランは平面的なものに止まらず，高度も含 めて一種の三次元的な空間構成上考えなければならないのである。

龍穴の前方の朱雀に相当する案山は, 左・中・右寄りの別があ り, 龍穴上の建造物の向きや位置の高低或いは左・右また正中に あるかどうか，すべて案山の高低遠近の次第である（図一7）。 案山が高すぎたり近すぎたりすると, 山の存在が強く意識されす ぎるので, 龍穴を压迫する恐れがある。案山が低すぎたり遠すぎ たりすれば, 山は概念的な存在と見なされ,「気」を散じやすいと 考えられるのである（空ける空間が広すぎて守れるものがない）。 従って, 案山の所在は直接に龍穴の位置に影響を与える（网一-8)。 その具体的な目安は, 龍穴の位置から案山の山稜線を見て, その最 頂点は眉に等しい, 最低点は心に応ずるという原則である(図-9)。

\section{（4）穴前（龍穴の前方）空間に対する景観の修景}

龍穴の前（墓ならば墳前，建造物ならば建築物の正面）の青龍 と白虎の山脈に囲まれた平坦な広場を「明堂」と称する。「明堂」 というのは，天子が群臣の崇めを受ける場所や臣を集めて政事を 合議する場所を意味するのである。風水で言う「明堂」とは龍穴 に対して礼拝するところであり，また龍穴から溢れた「気」の結 集する空間でもあると意識されている ${ }^{16)}$ 。「明堂」となる条件と しては方・正・平・円という形態，さらに龍穴に向かって有情な 形状（龍穴に向かって湾曲に抱かれる形を有情という）が要求さ れている。即ち整形の平坦地が望まれるのである。したがって, 龍穴の前の空間が傾斜, 散乱, 破砕, 無情（龍穴に反逆する）の 風景であれば，「気」を集結しないと見なされ，人工的な補修や 修景などの作業を工夫しなければならないのである。

具体的な龍穴の前（案山の方向）の景観の修景として, 崩れた 山の補強や盛士, 秃山の植林, 或いは流れの激しい河川に対する 改修作業が行われるのである。また，自然景観のバランスを重視 して, 地形の傾斜, 景観の欠陷がある場合は, 楼閣や風水塔を建 設したり（図-10), 土石を積んだりといった修景も行われてい $3^{17)}$ 。その他, 景観の完全な美を求めるために, 龍穴の前方の風

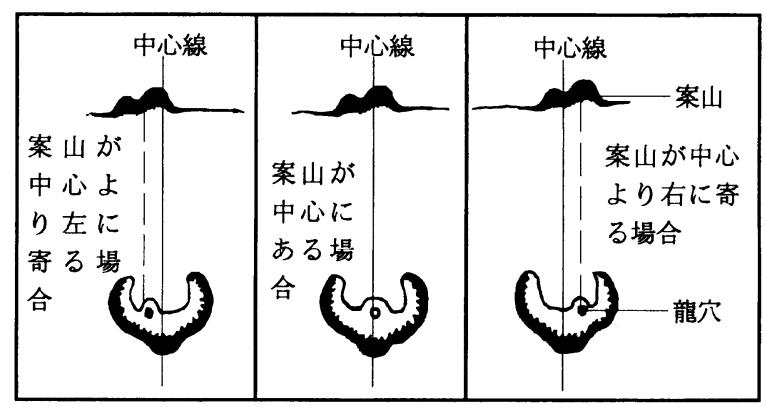

図-7 案山の所在と龍穴の位置 
景が散乱, 破砕した状況にあれば，植林により隠蔽するという手 法むよく風水術に使われる。

\section{6. まとめ}

以上の風水理念の解析や風水技法の考察の結果，風水思想にお ける自然景観の捉え方を次のようにまとめることができる。 (1) 古代から伝承される風水思想の思惟世界においては，大地は ひとつの生命体と見なされ, さらに生活空間としての物理的な地 形と一体になるという「天人合一」の理念が実現されている。 (2) 風水によって敷地を選定する際, 自然地形の変化に対する注 意深い観察がなされており, 風水とはまた自然環境の微地形を分 析する方法論でもあると考えられる。

(3) 風水思想の「蔵風納水」という風や水を制御する理念による 封閉空間から，風水に求められる理想的な環境之は外敵や風砂の 侵入を防ぐ構造を採用したという「防守保護」の概念であると理 解される。

(4) 風水による選地や造営物の建て方は, 前方の山の形や周囲の 地形に合わせるような位置や規模となるよう考虑されている。つ まりこれらは自然環境の一部であり, 自然の条理に従ってその配 置等を合致させなければならないという理念によるものと言える。 (5) 風水で重視される地形の対称性を保つことやその高低, 凸凹 を調和させることによる「陰陽調和」への配慮とは, 一種の景観 のバランスを重視することとも見られる。したがって視覚景観の 不均衡な場所や傾斜した場所に対しては, 人工的な遮粫や構築を 加えて, 景観のバランスを取り戻すという修景の行為も行われる。 (6) 風水による地形や景観の欠陥を補うための盛土, 植林, 河川 改修などは，結果として環境保全の効果をむつことから，風水技

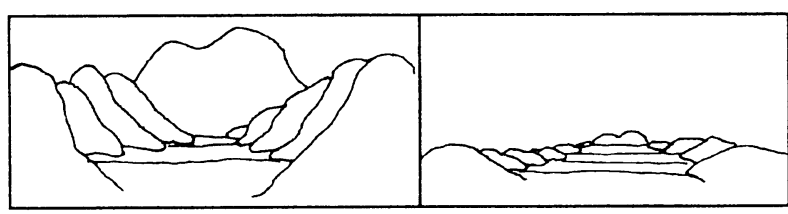

図－8 龍穴から見た近すぎる案山（左）と遠すぎる案山（右）

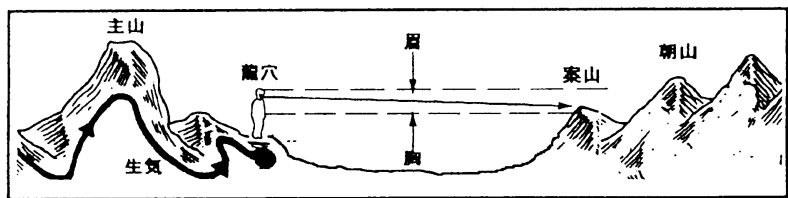

図-9 龍穴の位置と案山の高さの関係

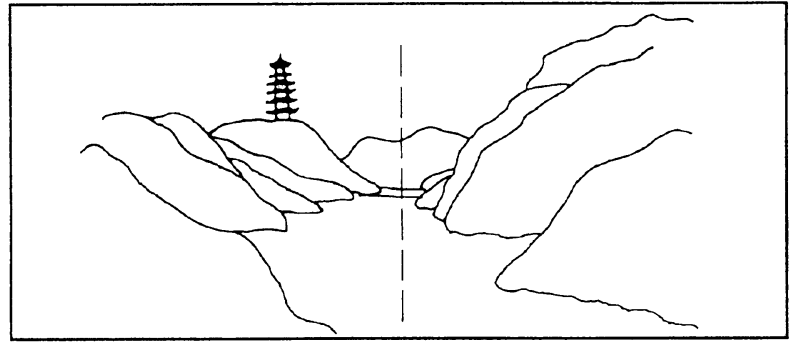

図ー10 左右の景観のバランスを風水塔によって補う

法は治山治水の役割を果たしていたと考えられる。

風水思想におけるこのような自然環境ないし景観の捉え方が如 何に実際の都市建設等に反映したかについて既報（注 $2 ， 3$ )で一 部論じたところである。今後さらに具体事例の分析を加え, 風水思 想がもつ環境計画手法としての体系的な認識を試みて行きたい。
注釈：1）『水法極玄』(司馬陀頭, 『堪興 奇書』に所収, 喜年来出版, 1986 年) に 「夫石為山之骨, 上為山之肉, 水為山之血 脈, 草木為山之皮毛, 骨肉皮毛, 皆血脈之 貫通也。」とある。

2) 黄 永融・本多昭一「日本古代宮都の 敷地選定と中軸線計画についてー一風水思 想からみた古代宮都計画の研究」, 日本建 築学会計画系論文集，474 号 1995，8

3 ）黄 永融・鳴海邦碩「清代末期におけ る台北市街地の形成過程とその特質に関す る考察」1995 年度第 30 回日本都市計画学 会学術研究論文集。

4 ) 『青鳥経註』(唐・楊均松, 『地理天機 會元』に所収, 武陵出版, 1986 年)「陰陽 符合。天地交通。内気萌生。外気成形。内 外相乗。風水自成。」とある。

5 )『葬経』に（晋・郭璞,『地理天機會元』 に所収, 武陵出版, 1986 年)「夫陰陽之気 噫而為風, 升而為雲, 降而為雨, 行乎地中 而為生気。」とある。

6 )『葬経』に（晋・郭璞,『地理天機會元』
に所収, 武陵出版, 1986 年)「気乗風則散, 界水則止, 古人聚之使不散, 行之使有止, 故謂之風水。」とある。

7 )『地理人子須知』(明・徐善継・徐善述 竹林書局 1989）「地理家, 以山名龍何也, 山之変態千形萬状, 或大或小, 或起或伏, 或逆或順, 或隠或顕, ...惟龍為然, 故以 名之, 取其潜見飛躍, 変化莫測」とある。 8 )『地理人子須知』(明・徐善継・徐善述, 竹林書局, 1989 年)「日脈者（龍脈）何也, 人身脈絡気血所由，運行而一身」とある。 9 )『雪心賦』(唐・卜則巍, 『地理天機會 元』に所收, 武陵出版, 1986 年）「穴者 (龍穴)，蓋猶人身之穴」とある。

10）『雪心賦』に「但求穴裏蔵風」之, 『葬 経』に「風水之法, 得水為上, 蔵風次之」 とある。

11）例えば, 日本の平安京の遷都の詔に 「山河襟帯, 自然作城」之記されている。 12）例えば『地理人子須知』巻六上に「合 襟水者，穴前界脈，上分下合之水。如胸前 衣襟之交合, 故名合㯲水也。蓋脈来則有分
水以導之, 脈止則有合水以界之」之記した。 つまり胸の前に（龍穴の前）衣の㯲を合わ せているような形勢を指す。

13）『黄囊経』(唐・楊均松, 『地理天機會 元』に所収, 武陵出版, 1986 年) に「天 心生突窟, 十道微微正好扞」とあり, 『地 理人子須知』に「天心十道者, 前後左右四 応之山也, 穴法得後有蓋山, 前有照山, 左 右画畔有夾耳之山, 謂之四応」とある。

14）四神相応の概念に関する二十八宿に記 載は『史記』の「天官書」や『淮南子』の 「天文訓」或いは『漢志』などに記載され る。

15）例えば, 南京の獅子山, 覆舟山, 台湾 基隆の鶏龍山などがある。

16）『金璧玄丈』（宋・廖金精, 『地理天機 會元』に所収, 武陵出版, 1986 年) に 「明堂気聚左右抱（明堂に気を集めて, 左 右の青龍・白虎に抱かれる)」とある。

17）例えば前方の山稜線の右側が高く, 左 側が低い場合は左の山頂に風水塔を建て, 左右のバランスを補う手法である。

Summary : Feng-shui, one of the eastern ideas, proposed the earth as a "creature". The idea of Feng-shui teaches us that the mountain would not be composed by the mineral and soil but has soul and spirit of a "dragon" (ryuu). The stone reflects the mountain's "bone"; the soil is the mountain's "meat"; and the vegetation is defined as the mountain's "skin or epidermis". The bone, meat and skin are connected by the river which is as the mountain's "blood line". The earth has been considered as a metaphor of the human body, so that we should keep in mind "the unity of people and nature". In this way, Feng-shui as the eastern theory contributes a specific useful technique in reading the landscape to find a natural principle for planning and designing building and space. 